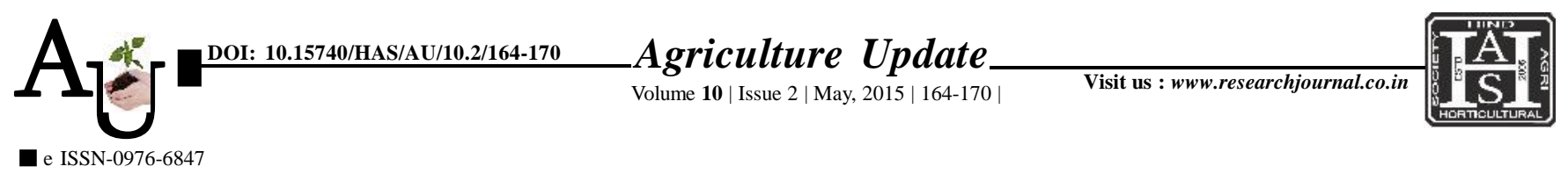

\title{
Research Article: KVK a knowledge resource centre; awareness among Navsari district farmers
}

\section{B.M. TANDEL*, K.A. SHAH AND PRABHU NAYAKA}

Article Chronicle : Received :

20.03.2015;

Revised :

06.04.2015;

Accepted :

19.04.2015

\section{KeY Words:}

Knowledge resource centre, Awareness, $\mathrm{KVK}$
Author for correspondence :

\section{B.M. TANDEL}

Krishi Vigyan Kendra (N.A.U.), NAVSARI (GUJARAT) INDIA

Email: hariombhupi@ gmail.com

See end of the article for authors' affiliations
SUMMARY : Ten each adopted and non-adopted villages of Krishi Vigyan Kendra were selected for the study purpose under KVK jurisdiction. Total 120 respondents were selected for the study. The teacher's made interview schedule was used for the data collection. The data were tabulated, analyzed and interpreted. The results revealed that there was significant association found between education and extent of awareness about knowledge resource centre established by KVK in adopted villages whereas in non-adopted villages significant association found between education, social participation, extension participation and extent of awareness about knowledge resource centre established by Krishi Vigyan Kendra.

How to cite this article : Tandel, B.M., Shah, K.A. and Nayaka, Prabhu (2015). KVK a knowledge resource centre; awareness among Navsari district farmers. Agric. Update, 10(2): 164-170. 